\title{
Determination of Some Air Pollutants and Meteorological Parameters in Abattoir, NTAK INYANG in UYO L.G.A of AKWA IBOM State in Nigeria
}

Jonah, A. E.

Department of Science Technology, AKWA IBOM State Polytechnic, IKOT Osurua, AKWA IBOM State, Nigeria.

\begin{abstract}
The determination of air pollutants in Abattoir, Ntak Inyang in Uyo L.G.A was carried out using standard analytical techniques. The pollutants monitored were $\mathrm{NO}_{2}, \mathrm{SO}_{2}, \mathrm{H}_{2} \mathrm{~S}, \mathrm{CO}, \mathrm{NH}_{3}, \mathrm{Cl}_{2}, \mathrm{TVOC}, \mathrm{CH}_{2} \mathrm{O}, \mathrm{PM}_{2.5}, \mathrm{PM}_{10}$, Temp, Relative humidity (RH), Pressure and Wind Speed (WS). The results for the concentration of air pollutant and their Air Quality Index (AQI) reveals as follows $\mathrm{NO}_{2}(1.36 \pm 0.32(\mathrm{ppm}), \mathrm{AQ1}=1360) . \mathrm{SO}_{2}(2.44 \pm$ 1.98(ppm), $A Q 1=488) . \quad H_{2} S(3.38 \pm 1940(\mathrm{ppm}), A Q 1=19450) . \mathrm{CO}(1.79 \pm 1.61(\mathrm{ppm}), A Q 1=334) . \quad \mathrm{NH}_{3}$ (7.8 $\pm 2.26(\mathrm{ppm}), A Q 1=156) . C l_{2}(1.47 \pm 1.29(\mathrm{ppm}), A Q 1=147) . H C N\left(11.56 \pm 7.93\left(\mathrm{mg} / \mathrm{m}^{3}\right), A Q 1=115,600\right)$. TVOC $\left(164 \pm 0.46\left(\mathrm{mg} / \mathrm{m}^{3}\right), \quad A Q 1=328\right) . \quad \mathrm{CH}_{2} \mathrm{O}\left(0.23 \pm 0.12\left(\mathrm{mg} / \mathrm{m}^{3}\right), \quad A Q 1=0.276\right) . \quad P M_{2.5} \quad\left(43.2 \pm 0.95\left(\mu \mathrm{g} / \mathrm{m}^{3}\right)\right.$, AQ1=172.8). $P M_{10}\left(74.8 \pm 1.15\left(\mu \mathrm{g} / \mathrm{m}^{3}\right), A Q 1=149.6\right)$. Temp $\left(27.5 \pm 4.6^{\circ} \mathrm{C}\right)$. Relative humidity $(\mathrm{RH})(74.6 \pm$ 4.6\%), Press (1006.7 $\pm 0.84(\mathrm{kpa})$. W.S $(1.56 \pm 0(\mathrm{~m} / \mathrm{s}))$. The result showed that $\mathrm{NO}_{2}, \mathrm{SO}_{2}, \mathrm{H}_{2} \mathrm{~S}, \mathrm{CO}, \mathrm{NH}_{3}, \mathrm{Cl}_{2}, \mathrm{HCN}$, TVOC, $P M_{2.5}$ and $P M_{10}$ were higher than that of FEPA standard limit. The correlation analysis revealed that $\mathrm{NO}_{2}$ shows positive relationship with $\mathrm{H}_{2} \mathrm{~S}$, and W.S at 0.05 significant level and negatively with $\mathrm{Cl}_{2}$ and Press at 0.01 significant level, and negatively with $\mathrm{PM}_{2.5}$ and $\mathrm{PM}_{10}$ at 0.05 significant level. $\mathrm{SO}_{2}$ correlated positively with $\mathrm{CO}$ at 0.01 significant level, TVOC and $\mathrm{CH}_{2} \mathrm{O}$ at 0.05 significant level. $\mathrm{SO}_{2}-\mathrm{NH}_{3}$ at 0.05 significant level but negatively. $\mathrm{H}_{2} \mathrm{~S}$ shows a relationship with Temp but positively at 0.01 significant level and 0.05 significant level with $\mathrm{HCN}, \mathrm{H}_{2} \mathrm{~S}$ also correlated negatively with $\mathrm{NH}_{3}$ and Press at 0.01 significant level. While CO shows a correlation with $\mathrm{NH}_{3}$ at 0.05 significant level but negatively. $\mathrm{NH}_{3}-\mathrm{RH}$ positively at 0.01 significant, $\mathrm{NH}_{3}$-Press at 0.05 significant level. Also, $\mathrm{NH}_{3}$ shows a negative relationship with TVOC, $\mathrm{CH}_{2} \mathrm{O}$ and Temp at 0.05 significant level. $\mathrm{Cl}_{2}$ correlated strongly but positively with Press at 0.01 significant level, $C_{2}-P M_{2.5}$ and $P M_{10}$ at 0.05 significant level and a negative relationship with W.S at 0.05 significant level. HCN-WS negatively at a 0.05 significant level. TVOC correlated positively with $\mathrm{CH}_{2} \mathrm{O}$ and negatively with $\mathrm{RH}$ at 0.01 significant level, and a positive relationship with $\mathrm{PM}_{2.5}$ and $\mathrm{PM}_{10}$ at 0.05 significant level. $\mathrm{CH}_{2} \mathrm{O}$ correlated negatively with $\mathrm{RH}$ at 0.01 significant level and positively with $P M_{2.5}$ and $P M_{10}$ at 0.05 significant level. $P M_{2.5}$ shows a positively relationship with $P M_{10}$ at 0.01 significant level. This result in an indication of the presence of possible air pollutants in the of the study area which may results in many health problems.
\end{abstract}

Key words: Pollution, Air Pollution and meteorological parameters.

\section{INTRODUCTION}

Atmospheric pollution is a condition in which certain substances, which include gases (sulphur dioxide, nitrogen dioxides, carbon monoxides hydrocarbons etc.), particulate matters (smoke, dust, fumes, aerosols, etc.), radioactive materials and many others are present in such concentrations that may produce undesirable effects on man and ecosystem [17].

Human exposure to air pollutants is unavoidable in today's perspective especially in the urban areas of most developing countries. Though, air pollution could be due to natural sources, a major anthropogenic source of air pollutant is due to man's quest for a better standard of living and the utilization of natural sources for rapid industrialization, urbanization and consequently causing excessive air pollution. Hence, air pollution problems have continued to receive a great deal of interest worldwide due to its negative impact on human health and welfare [4]. Among the reported cases of extreme air pollution conditions that affects humanity include the issues of high blood pressure and cardiovascular problems [17]. Air pollution, therefore, is a serious threat to environmental health in many cities of the world today. 
An abattoir is a slaughterhouse, or a place where animals are killed.[7]. Studies in Nigeria and other developing countries have established that poor waste management is responsible for the environmental and health hazards associated with abattoirs.

The hazards have indirectly threatened or endangered the health of residents and the environment in general. This is because animal waste such as blood, bones, intestinal content, tissues, hides and skin are scattered in huge piles around the abattoirs [14]. For example, waste generated in abattoirs is usually directed into rivers or the run-off gutters of adjoining buildings. This attracts flies and a stench that affects adjoining residences [9].

The waste water emanating from abattoir pollutes surface and underground water as well as the air. The pungent stench forces neighboring residents to shut their windows and doors, thus disallowing cross ventilation in homes. The piled-up waste also causes air pollution, which subsequently produces methane gas that intensifies the greenhouse effect on global warming. As a result, abattoirs-related environmental and health hazards have become prevalent [13].

\section{THE STUDY AREA}

Abattoir which is the focus of this study is located at Uyo in Ntak Inyang of Akwa Ibom State. Uyo lies between longitude $007^{0} 55^{1} 41.9^{11} \mathrm{~N}$ and latitudes $05^{\mathrm{O}} 04^{1} 22.5^{11} \mathrm{~N}$ and Elevation $44(\mathrm{~m})$, An average number of slaughtered animals per day are like 200 cows or more, even sheep and goats. Normal abattoir operations are carried out from Monday to Saturday.

\section{MATERIALS}

Equipment used in detecting the air pollutants are listed in the table below.

Table 1: Materials used in determining the air pollutants

\begin{tabular}{ll}
\hline Parameters & \multicolumn{1}{c}{ Equipment's Model } \\
\hline $\mathrm{NO}_{2}$ & $\mathrm{NO}_{2}$ gas monitor Gasman Model 19648H \\
$\mathrm{SO}_{2}$ & $\mathrm{SO}_{2}$ gas monitor Gasman Model 19831H \\
$\mathrm{H}_{2} \mathrm{~S}$ & $\mathrm{H}_{2} \mathrm{~S}$ gas monitor Gasman Model 19502H \\
$\mathrm{CO}$ & $\mathrm{CO}$ gas monitor Gasman Model 19252H \\
$\mathrm{NH}_{3}$ & $\mathrm{NH}_{3}$ gas monitor Gasman Model 1973OH \\
$\mathrm{Cl}_{2}$ & $\mathrm{Cl}_{2}$ gas monitor Gasman Model 19812H \\
$\mathrm{HCN}$ & $\mathrm{HCN}$ gas monitor Gasman Model 19773H \\
$\mathrm{TVOC}$ & $\mathrm{TVOC}_{\text {gas monitor Gasman Model Air Ae Steward air quality monitor }}$ \\
$\mathrm{CH}_{2} \mathrm{O}$ & $\mathrm{CH}_{2} \mathrm{O}$ gas monitor Gasman Model Air Ae Steward air quality monitor \\
$\mathrm{PM}_{2.5}$ & $\mathrm{PM}_{2.5}$ gas monitor Gasman Model Air Ae Steward air quality monitor \\
$\mathrm{PM}_{10}$ & $\mathrm{PM}_{10}$ gas monitor Gasman Model Air Ae Steward air quality monitor \\
\hline
\end{tabular}

Other instrument was, Max/Min Thermometer (Model No: KTJTA 318) used for measuring the temperature and digital Anemometer (MASTECH MS 6252A)

Determination of Air Quality Index

Air quality index (AQI) is an overall measure of the status of a place under consideration. On the basis of air quality index "Q", the quality rating of each parameter was obtained by the formula given below [2].

$\mathrm{Q}=(\mathrm{O} / \mathrm{Ps}) \mathrm{X} 100$

Where:

$\mathrm{Q} \quad=\quad$ Quality Ratings

$\mathrm{O}=$ Observed value

Ps $\quad=\quad$ Prescribed Standards as Permissible Limit.

Subsequently, the geometric mean of this "n" number of quality ratings "Q" was

estimated, which is known as AQI.

\section{RESULTS AND DISCUSSION}




\section{RESULTS}

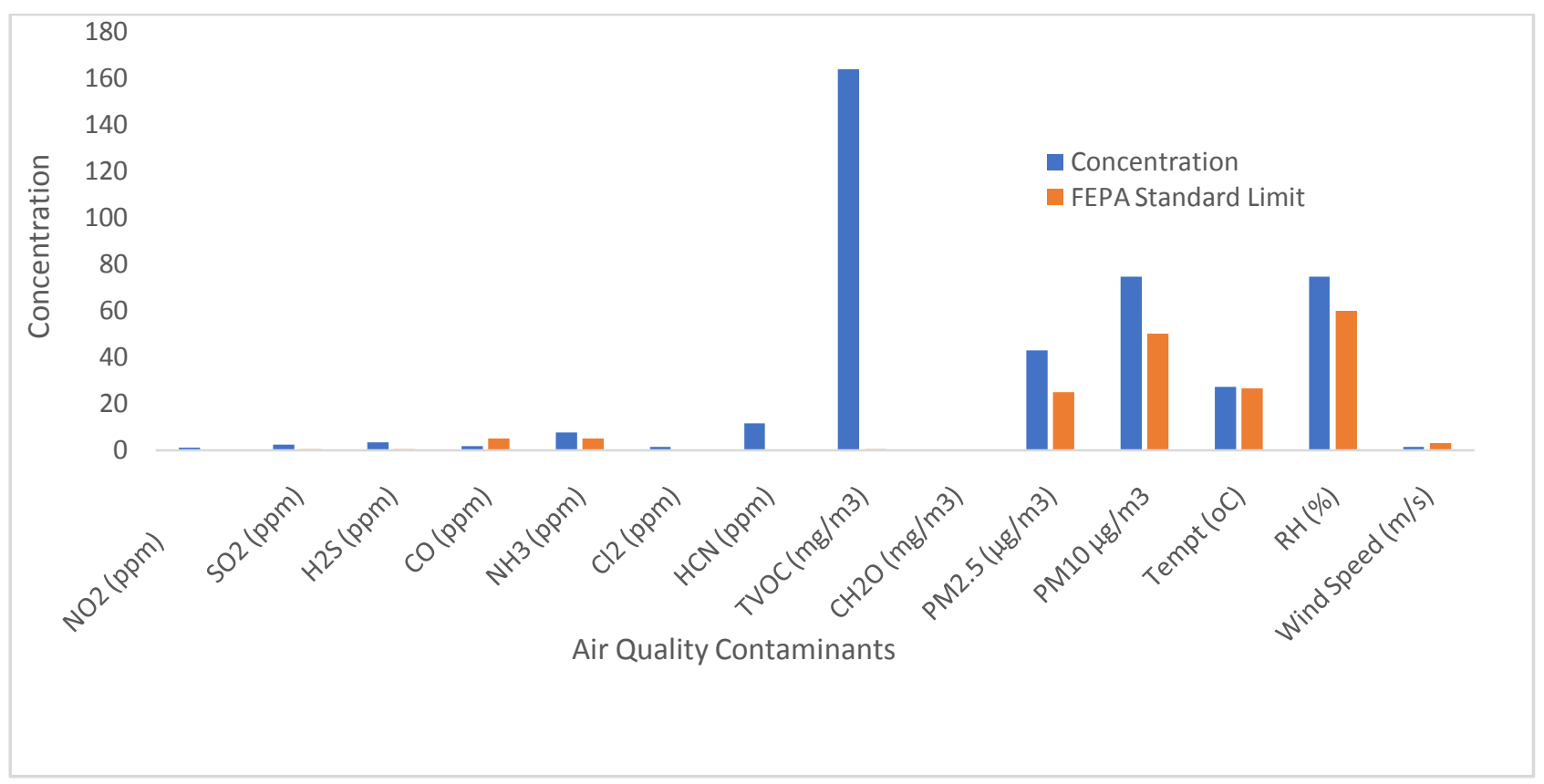

Figure 1: The Result of Some Air Pollutants and Meteorological Parameters in Abattoir, Ntak Inyang in Uyo L.G.A of Akwa Ibom State in Nigeria

FEPA -Federal Environmental Protection Agency

Table 2: The Air Quality Index of Air Pollutants Analyzed

\begin{tabular}{ll}
\hline Air Quality Contaminant & AQI \\
\hline $\mathrm{NO}_{2}(\mathrm{ppm})$ & 1360 \\
$\mathrm{SO}_{2}(\mathrm{ppm})$ & 488 \\
$\mathrm{H}_{2} \mathrm{~S}(\mathrm{ppm})$ & 1940 \\
$\mathrm{CO}(\mathrm{ppm})$ & 334 \\
$\mathrm{NH}_{3}(\mathrm{ppm})$ & 156 \\
$\mathrm{Cl}_{2}(\mathrm{ppm})$ & 147 \\
$\mathrm{HCN}(\mathrm{ppm})$ & 115600 \\
$\mathrm{TVOC}\left(\mathrm{mg} / \mathrm{m}^{3}\right)$ & 328 \\
$\mathrm{CH}_{2} \mathrm{O}\left(\mathrm{mg} / \mathrm{m}^{3}\right)$ & 0.276 \\
$\mathrm{PM}_{2.5}\left(\mu \mathrm{g} / \mathrm{m}^{3}\right)$ & 172.8 \\
$\mathrm{PM}_{10} \mu \mathrm{gg} / \mathrm{m}^{3}$ & 149.6 \\
\hline
\end{tabular}

Table 3: Air quality categorizes based on the air quality index by central pollution control board (CPCB), 2009. Source: CPCB (2009), AQI- Air Quality Index 


\section{DISCUSSION}

Nitrogen (iv) oxide $\left(\mathrm{NO}_{2}\right)$ recorded a mean concentration of $(1.36 \pm 0.32 \mathrm{ppm})$. The valve in above the range of 0.1 set by FEPA and could rise beyond this if control measures are not put in place, prolong inhalation

\begin{tabular}{lll}
\hline S/N & AQI of Ambient Air & Prescription of Ambient Air Quality \\
\hline 1 & $<10$ & Clean \\
2 & $10-25$ & Clean \\
3 & $25-50$ & Fairly Clean \\
4 & $50-75$ & Moderately Polluted \\
5 & $75-100$ & Polluted \\
6 & $100-125$ & Heavily Polluted \\
7 & $>125$ & severely polluted
\end{tabular}

of $\mathrm{NO}_{2}$ has been reported to cause premature death, stroke, heart disease, lung cancer, lung infection, asthma and chronic obstructive pulmonary diseases respiratory infection in children, coughing and wheezing [6]. This value, when subjected into air quality index (AQI) reveals that, the air is severely polluted

The mean concentration of sulphur (iv) oxide $\left(\mathrm{SO}_{2}\right)$ recorded was $2.44 \pm 1.98 \mathrm{ppm}$ ) which is above the range of $0.05-0.5 \mathrm{ppm}$ recommended by FEPA. This shows that $\mathrm{SO}_{2}$ is as higher rate and constant exposure air around the site may result in eye problem, mucous membrane, respiratory tracks redness and blister of skin, Bronchospasm edema, pneumonitis and acute air-way obstruction [1]. This value, when subjected into air quality index (AQI) reveals that the air is severely polluted.

Hydrogen sulphide $\left(\mathrm{H}_{2} \mathrm{~S}\right)$ recorded a mean concentration of $(3.88 \pm 1.05 \mathrm{ppm})$. This range is above the federal environmental protection agency (FEPA) range $(0.15-0.2 \mathrm{ppm})$ as thus, an indication the air quality around the study sit in poor and could possess some health problem such as cough, premature death, respiratory infection, cancer [12]. This value when subjected into Air Quality Index (AQI) reveals that, the air is severely polluted.

Carbon monoxide shows a mean concentration of $(179 \pm 1.61 \mathrm{pmm})$. This value in within the standard range (1.0-5.0ppm) set by FEPA. High CO may result in death as the gas combine readily with hemoglobin in red blood displacing oxygen and forming insoluble carboxyhemoglobin. It may also lead to tissue damage after prolong exposure and its affinity for hemoglobin is almost 220 times greater than that of oxygen [20]. This value, when subjected to air quality index (AQI), reveal that, the air is fairly clean which fall in a range of (25$50)$.

Ammonia $\left(\mathrm{NH}_{3}\right)$ recorded a mean concentration of $(7.8 \pm 2.26 \mathrm{ppm})$. This value is above the Federal Environmental Protection Agency (FEPA) range of (2.0-5.0ppm) health problem in human. The high concentration of ammonia recorded may be accredited to agricultural process, vehicular emission and vitalization from soils and ocean as reported by [3]. This value when subjected to air quality index (AQI) reveals that, the air in severely polluted.

The mean concentration of chlorine $\left(\mathrm{Cl}_{2}\right)$ ranges from $(1.47 \pm 1.29 \mathrm{ppm})$. This value is above the FEPA range of $(0.03-0.1 \mathrm{ppm})$ consequently inhalation of these gas may lead to attack on the respiratory system, eye problem and skin effect. The high level of chlorine from this study arise from burning of PVC rubbers and tire which are used in roasting the skin of the animals. This value when subjected to air quality index (AQI) reveal that, the air severely polluted. 
Hydrogen cyanide shows a mean concentration of $11.56 \pm 7.93 \mathrm{ppm})$. this value is highly above the limit range setas in [10] $(0.01 \mathrm{ppm})$. the high level of hydrogen cyanide reported for this study may be from burning of rubbish containing PVC. Prolong inhalation of HCN gas may lead to human poison, respiratory problem. When subjected into air quality index (AQI) reveals that, the air is severely polluted.

Volatile organic compound recorded a mean concentration of $\left(1.64 \pm 0.46 \mathrm{mg} / \mathrm{m}^{3}\right)$ this value in above the standard limit $\left(0.33-0.5 \mathrm{mg} / \mathrm{m}^{3}\right)$ as in[10]. This high levels of TVOC recorded may be due to burning of PVC rubbers and tire which are used in roasting the skin of the animals. Hence concentration of VOCs in the study area may result in death, lead to several dung or to human health like cough, lunge problem and environmental effects reportedas in[19]. This value when subjected into air quality index (AQI) reveal that, the air in severely polluted.

The mean concentration of formaldehyde $\left(\mathrm{CH}_{2} \mathrm{O}\right)$ reported was $\left(0.23 \pm 0.12 \mathrm{mg} / \mathrm{m}^{3}\right)$. This value is above the range of $\left(0.012 \mathrm{mg} / \mathrm{m}^{3}\right)$ set as in [10] and could rise beyond that if adequate measure is not taken. Prolong inhalation of these gas may lead to significant danger to human health such as heart disease lung cancer, premature death reported as in[15]. This value when subjected into air quality index (AQI) reveal that the air was very clean.

Suspended particular matter (SPM) is a term used to indicate very small solid and liquid particles in the air particulates matter $\left(\mathrm{PM}_{2.5}\right)$ obtain from this study show the second highest a mean concentration of $(43.2 \pm$ $\left.0.95 \mu \mathrm{g} / \mathrm{m}^{3}\right)$ the value is above the standard limit of $\left(25 \mu \mathrm{g} / \mathrm{m}^{3}\right)$ set as in [10]. These high level of $\mathrm{Spm}_{2.5} \mathrm{recorded}$ may be due to as a result of massive burning of tire in the study area. Hence concentration of $\mathrm{PM}_{2.5}$ in the study area may result in lungs and heart conditions eye infection, asthma, chronic bronchitis in people exposed it for a long time [8]. This value when subjected into air quality index (AQI) reveal that, the air is severely polluted.

Particulate matter $\left(\mathrm{PM}_{10}\right)$ recorded a mean concentration of $\left(74.8 \pm 1.15 \mu \mathrm{g} / \mathrm{m}^{3}\right)$. This value is higher than the range of $\left(50 \mu \mathrm{g} / \mathrm{m}^{3}\right)$ set as in [10]. Study has shown that this high concentration may be as a result of massive burning of tire in the study area. Hence prolong inhalation of $\mathrm{PM}_{10}$ may lead to cough, eye infection, asthma in respiratory and cardiovascular disease death reported as in [16]. This value when subjected into air quality index (AQI) reveal that, the air is severely polluted. 
TABLE 4: correlation of gaseous pollutants with some meteorological parameters.

\begin{tabular}{|c|c|c|c|c|c|c|c|c|c|c|c|c|c|c|c|}
\hline & $\mathrm{NO}_{2}$ & $\mathrm{SO}_{2}$ & $\mathrm{H}_{2} \mathrm{~S}$ & $\mathrm{CO}$ & $\mathrm{NH}_{3}$ & $\mathrm{Cl}_{2}$ & $\mathrm{HCN}$ & TVOC & $\mathrm{CH}_{2} \mathrm{O}$ & $\mathrm{PM}_{2.5}$ & $\mathrm{PM}_{10}$ & TEMP & $\mathrm{RH}$ & Press & W.S \\
\hline $\mathrm{NO}_{2}$ & 1 & & & & & & & & & & & & & & \\
\hline $\mathrm{SO}_{2}$ & 0.259805 & 1 & & & & & & & & & & & & & \\
\hline $\mathrm{H}_{2} \mathrm{~S}$ & $0.557605^{*}$ & 0.052706 & 1 & & & & & & & & & & & & \\
\hline $\mathrm{CO}$ & 0.147468 & $0.941136^{* *}$ & -0.08869 & 1 & & & & & & & & & & & \\
\hline $\mathrm{NH}_{3}$ & -0.41638 & $-0.6166^{*}$ & $-0.7834^{* *}$ & $-0.52185^{*}$ & 1 & & & & & & & & & & \\
\hline $\mathrm{Cl}_{2}$ & $-0.9885^{* *}$ & -0.36882 & -0.47868 & -0.24244 & 0.410094 & 1 & & & & & & & & & \\
\hline $\mathrm{HCN}$ & 0.206357 & -0.23423 & $0.555798^{*}$ & -0.0562 & -0.39731 & -0.0831 & 1 & & & & & & & & \\
\hline TVOC & -0.33012 & $0.608321 *$ & 0.14498 & 0.459858 & $-0.5431^{*}$ & 0.255382 & -0.33747 & 1 & & & & & & & \\
\hline $\mathrm{CH}_{2} \mathrm{O}$ & -0.36615 & $0.585734 *$ & 0.125126 & 0.443651 & $-0.52072^{*}$ & 0.292852 & -0.33691 & $0.999239 * *$ & 1 & & & & & & \\
\hline $\mathrm{PM}_{2.5}$ & $-0.6382 *$ & -0.25899 & 0.080436 & -0.40808 & 0.012703 & $0.645616^{*}$ & -0.28549 & $0.602509 *$ & $0.622896 *$ & 1 & & & & & \\
\hline $\mathrm{PM}_{10}$ & $-0.5402^{*}$ & -0.23195 & 0.263803 & -0.38706 & -0.15177 & $0.564364 *$ & -0.13508 & $0.621553^{*}$ & $0.638572^{*}$ & $0.980752^{* *}$ & 1 & & & & \\
\hline TEMP & 0.409194 & 0.197388 & $0.812167^{* *}$ & -0.09278 & $-0.67165^{*}$ & -0.39638 & -0.01955 & 0.48801 & 0.467829 & 0.413008 & $0.528681^{*}$ & 1 & & & \\
\hline $\mathrm{RH}$ & 0.329499 & -0.49485 & -0.35767 & -0.45784 & $0.715973^{* *}$ & -0.31341 & -0.15784 & $-0.8709 * *$ & $-0.8739 * *$ & -0.49842 & $-0.58417^{*}$ & -0.41452 & 1 & & \\
\hline Press & $-0.8015^{* *}$ & 0.074592 & $-0.88761^{* *}$ & 0.250007 & $0.525403 *$ & $0.730132^{* *}$ & -0.38826 & 0.178837 & 0.205202 & 0.142181 & -0.00437 & $-0.7410^{* *}$ & -0.0845 & $\begin{array}{l}1 \\
-\end{array}$ & \\
\hline W.S & $0.620567^{*}$ & 0.171011 & -0.13343 & -0.0035 & 0.229022 & $-0.69072^{*}$ & $-0.57983^{*}$ & -0.27881 & -0.30362 & -0.40154 & -0.46663 & 0.129536 & $0.647875^{*}$ & 0.2809 & 1 \\
\hline
\end{tabular}

** Correlation is significant at the 0.01 level (2 tailed)

* Correlation is significant at the 0.05 level ( 2 tailed 


\section{Correlation Analysis}

Correlation matrix in Table 4 has the following relationship among the air particulates.

$\mathrm{NO}_{2}$ shows a strong negative correlation between $\mathrm{Cl}_{2}$ and Press at 0.01 with ( $\mathrm{r}=-0.9885,-0.8015$ respectively) and 0.01 limit with $\mathrm{PM}_{2.5}, \mathrm{PM}_{10}(\mathrm{r}=-0.6382,-0.5402)$ this shows that as $\mathrm{NO}_{2}$ increases the concentration of $\mathrm{PM}_{2.5}, \mathrm{PM}_{10} \mathrm{Cl}_{2}$ and Press decrease and vice versa. However, there was a strong positive correlation between $\mathrm{NO}_{2}$ with W.S and $\mathrm{H}_{2} \mathrm{~S}$ at 0.05 level with $(\mathrm{r}=0.62057$ and 0.557605 respectfully). This shows that the source of $\mathrm{NO}_{2}$ may have also contributed significant concentration of $\mathrm{H}_{2} \mathrm{~S}$ and W.S into the air of environment studied.

$\mathrm{SO}_{2}$ correlated strongly positively with $\mathrm{CO}$ at 0.01 level $\mathrm{r}$ values $=0.941136$ and strongly but positively with TVOC and $\mathrm{CH}_{2} \mathrm{O}$ at 0.05 level with $(\mathrm{r}=0.608321$ and 0.585734 respectfully). This has revealed the common source of this pairs as reported in[18].Also, $\mathrm{SO}_{2}$ shows a strong negative relationship with $\mathrm{NH}_{3}$ at $\mathrm{NH}_{3}$ at 0.05 level with $(\mathrm{r}=-0.6166)$. This indicate that as $\mathrm{NH}_{3}$ increases $\mathrm{SO}_{2}$ decreases and vice versa.

Hydrogen sulphide shows a correlation relationship at 0.01 level with Temp with $(r=0.81216)$ and at 0.05 level with $\mathrm{HCH}$ with $(\mathrm{r}=0.555798)$. This has revealed the common source of this pairs of air contaminant reportedas in[18] that, high correlation among parameters signify their familiar source. HCN also correlated strongly negatively with Press and $\mathrm{NH}_{3}$ at 0.01 level respectively with $(\mathrm{r}=-0.8872167$ and -0.7834 respectively). This indicated that as pressure and $\mathrm{NH}_{3}$ increases $\mathrm{H}_{2} \mathrm{~S}$ decreases and vice versa. However, there was no significant correlation with others parameters.

Carbon monoxide (CO) correlated negatively but strongly with $\mathrm{NH}_{3}$ at 0.05 level with $(\mathrm{r}=-0.52185)$. Results shows that as $\mathrm{CO}$ increases the level of $\mathrm{NH}_{3}$ decreases and vice versa.

Ammonia show a positive strong correlation with RH at 0.01 level with $(r=0.715973)$ and Press at 0.05 level with $(\mathrm{r}=0.525403)$. This revealed that $\mathrm{RH}$ and Press may have emanated from a similar source with $\mathrm{NH}_{3}$ within the area studied. This correlation analysis also indicated that Temp, $\mathrm{CH}_{2} \mathrm{O}$ and TVOC showed a negative correlation with $\mathrm{NH}_{3}$ at 0.05 level with $(\mathrm{r}=-0.67165,-0.52072$ and -0.5431$)$. This indicated that as the concentration of $\mathrm{NH}_{3}$ increases that of Temp, $\mathrm{CH}_{2} \mathrm{O}$ and TVOC decreases and vice versa.

Correlation analysis between Chlorine and Pressure showed a strong positive relationship at 0.01 level with $(\mathrm{r}=0.730132)$ and at 0.05 level with $\mathrm{PM}_{2.5}$ and $\mathrm{PM}_{10}(\mathrm{r}=0.64516$ and 0.564364$)$. This shows that as the concentration of chlorine may have been as a result of increase in Press, $\mathrm{PM}_{2.5}$ and $\mathrm{PM}_{10}$ respectively. However, there was a negative relationship between $\mathrm{Cl}_{2}$ and W.S at 0.05 level with $(\mathrm{r}=-0.69072)$. These indicate that, as $\mathrm{Cl}_{2}$ decrease W.S increases and vice versa.

Correlation analysis between HCN and W.S shows negative relationships at 0.05 level with $(\mathrm{r}=-$ 0.57983). This indicate that as HCN decreases, W.S increases and vice versa.

TVOC shows a strong positive correlation with $\mathrm{CH}_{2} \mathrm{O}$ at 0.01 level with $(\mathrm{r}=0.999239)$ also with $\mathrm{PM}_{2.5}$ and $\mathrm{PM}_{10}$ at 0.05 level with $(\mathrm{r}=0.602509$ and 0.621553$)$. These shows that $\mathrm{CH}_{2} \mathrm{O}, \mathrm{PM}_{2.5}$ and $\mathrm{PM}_{10}$ may have emanated from a similar source with TVOC within the area of the study. However, there was a negative correlation between TVOC and RH at 0.01 level $(r=-0.8709)$. This shows that, as the concentration of TVOC increases that of RH decreases.

Formaldehyde shows a strong positive correlation with $\mathrm{PM}_{2.5}$ and $\mathrm{PM}_{10}$ at 0.05 level with $(\mathrm{r}=0.622896$ and 0.638572 ). This shows that $\mathrm{PM}_{2.5}$ and $\mathrm{PM}_{10}$ may have also contributed significant concentrations to the source of $\mathrm{CH}_{2} \mathrm{Oin}$ the air of the environment studied. Result also indicated that $\mathrm{CH}_{2} \mathrm{O}$ correlated negatively with RH at 0.01 level with $(r=-0.8739)$. These indicated that as $\mathrm{CH}_{2}$ Odecreases $\mathrm{RH}$ increases and vice versa.

$\mathrm{PM}_{2.5}$ shows a strong and positive correlation with $\mathrm{PM}_{10}$ at 0.01 level with $(\mathrm{r}=0.980752)$. This shows that $\mathrm{PM}_{10}$ may have emanated from a similar source with $\mathrm{PM}_{2.5}$ within the area studied.

Correlation analysis between $\mathrm{PM}_{10}$ and Temp at 0.05 level with $(\mathrm{r}=0528681)$. This indicates that, Temperature may have contributed significant to the concentration of $\mathrm{PM}_{10}$ in the air of the environment. There was a correlation but negative with RH at 0.05 level with $(r=-0.58417)$. This indicate that as RH decreases the level of $\mathrm{PM}_{10}$ increases and vice versa.

Temperature shows a negative correlation with press at 0.01 level with $(r=0.7410)$. Result indicate that as Temp decreases, Pressure increases and vice versa. 
There is a strong positive correlation between RH and W.S at 0.05 level with $r=0.647875$. This shows the common source of this pairs of air contaminants.

\section{CONCLUSION}

Based on the result of this research work, it was concluded that air in Abattoir, Ntak Inyang in Uyo L.G.Ain Nigeria contains concentrations of various pollutants under investigation. The presence of these pollutants at variable levels indicate possible health implications. The presence of these pollutants is due to some Abattoir activities within the area. The high concentration of particulate matter $\left(\mathrm{PM}_{10}\right.$, and $\left.\mathrm{PM}_{2.5}\right), \mathrm{CO}$ and $\mathrm{Cl}_{2}$, HCN, TVOC, may be attributed to massive burning of PVC rubbers and tire which are used in roasting the skin of the animals. Decomposition of organic wastes may be the major sources of these air contaminants/pollutants $\left(\mathrm{NO}_{2}, \mathrm{H}_{2} \mathrm{~S}, \mathrm{NH}_{3}\right)$ in the area under investigation.

\section{REFERENCES}

[1] Adelagun, R. O., Berezi, E. P.andAkintude, O. A. "Air pollution in a seamill industry: the Okababa (Ebute-meta, Lagos) experience". J. $\quad$ Sustain. Dev. Environ. Protection, vol.2(2),pp. 29-36, 2012

[2] Agarwal, S., Swami, I. B. and Gupta, A. B. "Interpretation of ambient air and Air Quality Parameters in Jaipur City - A case study". Nature Environment and pollution Technology, Vol.7 (4), pp. 573-578, 2008.

[3] Behera, S. N., Sharma, M., Aneja, V. P. andBalascubramania, R. "Ammonia in the atmosphere: A Review on emission sources, atmospheric chemistry and deposition on terrestrial bodies”. Environ. Sci. Pollut. Res. Int, vol.20(11),pp. 8092 - 8131, 2003

[4] Brunekreef, B., Hoek, G., Buregelmans, O. andLeevtvaar, M.” Respiratory Effects ofLow-levelPhotochemical Air Pollution in Amateur Cyclist.” Am. J. Clinical Care Me; vol.150, pp. 962-75. 2004

[5] CPCB. Standards for liquid equivalent gaseous emission Automobile Exhaust, Noise and Ambient Quality Pollutant control and law series: Ministry of Environment and forests Government of India, New Delhi 2005-2009.

[6] Cadle St, G., Jr, R. A., Bbuley, B. K. and Lawson, D. R.” Real-world vehicle emission: A summary of the twelfth coordinating research council on-road vehicle emission workshop". Journal of the Air and Waste Management Association, 53(2), pp. 152$167,2003$.

[7] Dictionary, Merriam-Webster, https://www.merriam-webster.com/dictionary/abattoir. Accessed 16 Oct. 2020).

[8] Efe, S. I. "Particulate pollution and its Health Implication in Warri Metropolis, Delta State Nigeria". Env. Anal, vol.11, pp. 133 9$1351,2006$.

[9] Fearon J., Mensoh S. B. and Vivian Boateng: Abattoir Operation, Waste Generation and Management in the Tamale Metroplolis: Case Study of Tamale Slaughter House. Academic Journal Vol. 6 Issue 1, 2014

[10] Federal Environmental Protection Agency (FEPA) "National Guidelines and Standards for Industrial Effluents, Gaseous Emissions and Hazardous Waste Management in Nigeria". Pp.59-66, 1991

[11] Federal Environmental Protection Agency (FEPA) of Nigeria. "National Master Plan for Public Awareness on Environment and Natural Resources Conservation in Nigeria”, FEPA, Garki, Abuja, 2000.

[12] Huang, C. Weihao, M. and Philip, K. " $\mathrm{H}_{2} \mathrm{~S}$ Synthesizing Enzymes Biochemistry and Molecular Aspect; Chemistry, Biochemistry and pharmacology of Hydrogen sulfide, Springer International Publishing, vol.230; pp. 3-25, 2015

[13] Nwachukwu, M. I, Akanide ,S. B, Udujih, O. S and Nwachukwu, I. O.'Effect of Abattoir Waste on the population of Proteolytic and Lipolytic bacteria in a recipient water body (Otanim River”. Global Research Journal, vol. 1, pp. 40-42,2011.

[14] (2019)Nigerian Health Watch (NHN): Your meat could be killing you: Nigeria Unhealthy Abattoirs. www. nigeriahealthwatch.com.

[15] Magnum, J. G., Darling, J., Menten, K. M. and Henkel, C. "Formaldehyde Densitometry of starburst Galaxies." Astrophys. J.,vol.673(2), pp. 832-46, 2008.

[16] Pelucche, C., Negri, E., Gallus, S., Boffeta, P., Cramacera, I. andLavechia, C.” Long-term particulate matter exposure and mortality: A review of European epidemiological studies", BMC Public Health, vol.,9, pp. 452 - 45, 2009.

[17] Pope, C. A. "Cardiovascular Mortality and Long-term Exposure to particulate Air Pollution: Epidemiological Evidence of General Path physiological Pathway of Diseases”. Circulation,vol.109 (1), pp.71-77, 2003.

[18] Romic, M. andRomic, D."Heavy metal distribution in agricultural top soil in urban areas”. Environ. Geol., vol,43, pp. 795 - 805, 2002

[19] Schlank, U., Rehwagen, M., Damm, M., Riebter, M., Borte, M. andHerbarth, O. (2004). "Seasonal Cycle of Indoor-VOCs Comparison of apartments and cities." Atmospheric Environment, vol. 38(8), pp. 1181-90, 2004

[20] Ukemenam, O. S. Causes and consequences of air pollutant in Nigeria. South A. J. Pub. Health, vol. 2(2), 293 - $30,2014$. 